\title{
'The Futurist mountains': Filippo Tommaso Marinetti's experiences of mountain combat in the First World War
}

\author{
Selena Daly* \\ University College Dublin, Dublin, Ireland
}

(Received 26 June 2012; final version accepted 10 October 2012)

\begin{abstract}
Filippo Tommaso Marinetti's first experience of active combat was as a member of the Lombard Battalion of Volunteer Cyclists and Motorists in the autumn of 1915, when he fought in the mountains of Trentino at the border of Italy and Austria-Hungary. This article examines his experience of mountain combat and how he communicated aspects of it both to specialist, Futurist audiences and to the general public and soldiers, through newspaper articles, manifestos, 'words-in-freedom' drawings, speeches and essays written between 1915 and 1917. Marinetti's aim in all of these wartime writings was to gain maximum support for the Futurist movement. Thus, he adapted his views to suit his audience, at times highlighting the superiority of the Futurist volunteers over the Alpine soldiers and at others seeking to distance Futurism from middle-class intellectualism in order to appeal to the ordinary soldier. Marinetti interpreted the war's relationship with the natural environment through an exclusively Futurist lens. He sought to 'futurise' the Alpine landscape in an effort to reconcile the urban and technophilic philosophy of his movement with the realities of combat in the isolated, rural and primitive mountains of Trentino.
\end{abstract}

Keywords: Filippo Tommaso Marinetti; Futurism; mountains; First World War; Trentino; alpini

\section{Introduction}

Prior to Italy's entry into the First World War in May 1915, Filippo Tommaso Marinetti, founder of the Futurist movement, and a number of other prominent Futurists had enrolled in the Lombard Battalion of Volunteer Cyclists and Motorists. Alongside Marinetti were the painters Umberto Boccioni, Luigi Russolo, Ugo Piatti and Mario Sironi and the architect Antonio Sant'Elia. In the summer months of 1915, the Volunteer Cyclists received training in Gallarate, near Milan, before leaving for Peschiera on the southern shores of Lake Garda at the end of July. In mid-October, the battalion was sent to the Italian-Austrian front line and stationed at Malcesine, on the eastern side of Lake Garda. The Volunteer Cyclists' principal experience of combat was in the capture of Dosso Casina in October when they fought alongside the elite Alpine soldiers. Their experience of fighting on the front line was destined to be short-lived, however. By the beginning of December, the Battalion of Volunteer Cyclists had been disbanded. So the Futurist volunteer cyclists returned, at least temporarily, to their pre-wartime

\footnotetext{
*Email: selena.daly@ucd.ie 
pursuits in Milan, although they 'anxiously await[ed] the pleasure of returning to battle' (Marinetti 1916c, 506).

In the years preceding Italy's entry into the war, numerous groups of volunteer cyclists were formed. These groups engaged in military-style training, including shooting and marching practice, and instruction on weapons, logistics and military tactics. In 1905, the Central Committee of Volunteer Cyclists and Motorists was established, which, in 1908, became an auxiliary military corps 'officially recognised by the Government, placed under high surveillance by the Ministry of War and charged with preparing the units of cyclists and motorists for the defence of the national territory' ${ }^{1}$ (État-Major de l'Armée 1908, 186). The cyclists were recruited on a regional basis and were formed into platoons of between 16 and 32 cyclists, which could then be grouped into larger battalions. All recruits had to be Italian citizens, over 16 years of age, in possession of a bicycle, motorcycle or automobile, and in good physical health. ${ }^{2}$ The Lombard Battalion of Volunteer Cyclists was mobilised on 23 May 1915 (on their activities during the war see Sansone 2008).

The Lombard Battalion was held in very high esteem by the people of Milan: when the cyclists travelled through the city on their way to Lake Garda in July 1915 the streets were crowded with supporters. As well as a military plane flying over them dropping leaflets in the Italian colours, the crowd 'applauded them, covered them with flowers, good wishes, and kisses' (Codara 1915a). A member of the Battalion, Angeluccio Giudici, recalled many years later that it was regarded as a 'forge of patriotism, they were the crucible of irredentist passion' (Giudici in Sansone 2008,16 ). While Italy was still neutral, many young irredentists from Trentino, Trieste and Dalmatia succeeded in crossing the border and they joined the Battalions of Volunteer Cyclists in various northern Italian cities. In turn, many of the battalions participated in interventionist demonstrations in 1915. As Marinetti commented, the Lombard Battalion contained the same men:

... students, monarchists, revolutionary workers, law-abiding lawyers ... persecuted anarchists,

Freemasons and clericalists, poor and wealthy, traditional painters and poets, avant-gardists,

Futurists and semi-Futurists, who had already met in the Piazza del Duomo and in the Galleria,

almost every evening, during the winter and spring, to punch and chase away the neutralists.

(Marinetti 1916d)

Given the make-up and ideology of the other members of the Battalion, it is not surprising that the Futurists regarded it as a good home for their bellicose aspirations.

This article will examine Marinetti's experience of mountain combat in Trentino during the autumn of 1915, asking how he interpreted this landscape and how he employed it in his contemporary writings. During his time on the Trentino front line Marinetti kept a diary, though the entries are not particularly substantial. Between 1916 and 1917, however, following the disbandment of the battalion, he produced a number of texts for public consumption - a manifesto, newspaper articles, drawings and even a self-help manual - which discuss and examine the period he spent in the Alps. The texts that referenced the mountain-combat experience had a dual function: on the one hand, Marinetti used his wartime experiences to bolster Futurist ideas and maintain support for them among Futurist intellectuals and sympathisers and, on the other hand, he sought to manipulate his experiences to gain support for Futurism, and for the war effort, from the general public and from his fellow, non-Futurist soldiers. In this article, I will principally examine how Marinetti communicated two aspects of his combat experience to these two different audiences - his perceptions first of the mountainous landscape itself and second of the soldiers who fought there, the alpini. 
The relationship between war and the environment is currently receiving an increasing amount of attention in the field of environmental history (Pearson 2012). One of the growing areas of interest in the environmental history of warfare is a consideration of 'soldiers' experience of landscape' (Pearson 2012, 8). The First World War has proved a particularly fertile ground for this line of enquiry. However, to date most attention has been focused on the trenches of the Western Front (Fussell 1975; Amat 1997; Saunders 2003; Helphand 2006; Brantz 2009; Wilson 2012). Tait Keller (2009) has broadened the horizon with his recent work on German and Austro-Hungarian experiences of combat in the Alps during the First World War and although the field of environmental history in Italy is still in its infancy, Marco Armiero (2010, 2011) has made important contributions to Italy's relationship with her mountainous landscape, before, during and after the First World War. Recent Italian works examining soldiers' experiences of fighting in the Alps in the Great War have not tended to focus specifically on how the soldiers perceived and interpreted their environment (Kuprian and Überegger 2006; Franzina 2003; Corà 2008; Leoni 2007). Marinetti's interpretation of the mountain landscape, as will be seen below, is atypical and thus contributes only peripherally to an overall understanding of Italian soldiers' interactions with the Alpine landscape. The significance of Marinetti's descriptions of his period in Trentino in texts published between 1915 and 1917 lies in how he succeeded in communicating his experience to other Futurists and to the general public, thus contributing to the development of the mythopoeia of mountain combat and the Alpine soldiers during the early period of the First World War.

\section{Marinetti and irredentism}

Although the principal focus of Futurism was in the realms of literature and the visual arts, from the outset the movement's manifestos and declarations also contained a political dimension. In the first manifesto of Futurism of February 1909, Marinetti stated that 'we wish to glorify war the sole cleanser of the world - militarism, patriotism ... beautiful ideas worth dying for' (Marinetti 1909a, 14). Marinetti demonstrated the political and patriotic aspect of his nascent movement through his engagement with the irredentist cause in Italy. He first became involved in the irredentist struggle while he was finalising the founding manifesto. In December 1908, Marinetti attended a memorial service in Trieste for the mother of Guglielmo Oberdan. Oberdan was hailed as a martyr of the irredentist and nationalist cause, after he had been executed by the Austrians in 1882 following his attempted assassination of the Austrian Emperor. At the 1908 memorial service, Marinetti laid a wreath at the tomb of Oberdan's mother and delivered a rousing anti-Austrian speech (Berghaus 1996, 48). Thus, irredentism and the birth of Futurism are very much intertwined, and the political aspects of the founding manifesto, while not specifically referring to irredentism, must be considered in relation to this cause.

Marinetti's commitment to irredentism continued during the pre-war period: in 1911 on the outbreak of war with Libya, he proclaimed the 'birth of PAN-ITALIANISM' (Marinetti 1911a, 74) and on 11 October 1913, he launched the Futurist Political Programme, in which one of the key tenets was 'Irredentism - Pan-Italianism - the supremacy of Italy' (Marinetti 1913, 75). The twin symbols of the irredentists in Italy were the cities of Trento and Trieste. However, in the early years of Futurist engagement with irredentism, the city of Trieste was of greater rhetorical importance for Marinetti than the city of Trento. Less than a year after the foundation of the movement, on 12 January 1910, Marinetti held the first Futurist serata in Trieste, which featured recitations of Futurist manifestos and poetry, 'in order to revive opposition to the Triple Alliance and to reawaken irredentism' (Marinetti 1915a, 337). Trieste was adopted by Marinetti 
as the representative of the unredeemed lands and he dubbed it 'our beautiful powder keg', stating that he placed all Futurist hopes in the city (Marinetti 1915d, 289). On the other hand, fighting on the Trentino front line with the Volunteer Cyclists in 1915 was the realisation of Marinetti's dream to participate in war as a soldier, an aim he had expressed since 1909. While Trieste in the pre-war years had been the focus of Futurist irredentist rhetoric, in 1915 Trentino became the locus of action and represented the culmination of Futurist declarations on irredentism, patriotism and direct engagement in war. ${ }^{3}$

Long before Marinetti had embarked for the Trentino front in 1915, mountains had held a fascination for him, not only as physical indicators of the frontier with Austria-Hungary, but also as symbols of his quest for artistic iconoclasm. The first Futurist manifesto of 1909 ended with an image of the Futurists 'standing tall on the roof of the world' (Marinetti 1909a, 16) threatening the dying and traditional stars, which were symbolic of the style of art and literature Marinetti wished to destroy. The second manifesto of Futurism from April of the same year, entitled 'Let's kill off the moonlight!', recounted an allegorical battle in which the Futurists conquered the summit of the world in the mountains of Asia and destroyed the passéist cities of Rome and Milan. These cities were represented as a blight on the 'beautiful mountain slopes' (Marinetti 1909b, 30). While on the one hand Marinetti intended to construct a military train track 'along the tops of all the mountains' (Marinetti 1909b, 26), he also wished to go beyond the mountains by harnessing the power of flight. The new perspectives offered by flight were ones that Marinetti was keen to incorporate into his Futurist vision: 'seeing things from a new perspective, no longer frontally or from behind, but straight down beneath me, and thus foreshortened, I was able to break the age-old fetters of logic and the leaden wire of traditional comprehension' (Marinetti 1912, 112). Although Marinetti's means of transport in 1915 was the bicycle and not the aeroplane, fighting on the Alpine slopes at heights of 3000 metres offered him a similar perspective to that which he had imagined as a result of flight. Thus, fighting in the mountain landscape of Trentino represented the realisation not only of his political aims, but also of his artistic and aesthetic dreams.

\section{Marinetti among the Volunteer Cyclists}

As a Volunteer Cyclist, Marinetti served as an ordinary soldier and so endured the same hardships as those experienced by the majority of Italian soldiers on the front lines. Both in his diary and in letters, he frequently complained of cold, hunger, lack of sleep and lack of supplies (see his diary entries in Marinetti 1987, 4-42). In January and February 1916, Marinetti wrote a two-part feature about his experiences in Trentino for La Gazzetta dello Sport (Marinetti 1916d, 1916e). In the second of these articles, he described how he and his fellow soldiers were 'without gloves, without balaclavas, with just a light cape, no wine, no alcohol, no coffee, one loaf of bread between four men, one tin of meat between three, Siberian wind in our bones' (Marinetti 1916e).

After the battle and successful conquest of Dosso Casina, the Comando dell' Altissimo 'sent warm congratulations to the Command of the Battalion for the execution of the fighting and for the determined and brave actions of the volunteers' (Codara 1915b). Nonetheless, shortly afterwards, the battalion was disbanded. In his article on the disbandment, La Gazzetta dello Sport journalist Renzo Codara stressed his opinion that the decision by the High Command to disband the battalion had not been in any way influenced by personal feelings towards the volunteers but rather was necessitated by the fact that the mountain warfare Italy was engaged in was unsuitable for soldiers on bicycles. He acknowledged that some would regard the step as the 
result of 'a decided dislike for the Volunteer Corps on the part of the higher ranks of the army' but refutes this accusation, stating that 'it is true that not everyone appreciates the volunteers, but it is also true that there are many admirers of the Volunteer Corps' (Codara 1915b). However, according to one former Volunteer Cyclist, the battalion was disbanded because they were 'rowdy' and unpopular with the army command (Francioli 2008, 40). Marinetti himself confirmed this 'rowdiness' in the second of his articles for La Gazzetta dello Sport, in which he recounted an evening when the entire battalion got drunk and was subsequently punished. Marinetti commented that the commanding sergeant of their battalion 'rightly demanded, but did not receive, absolute discipline, which we wanted to be relative' (Marinetti 1916d) and he acknowledged the very difficult task of commanding the 'intellectuals' platoon ... because in it, all together, were the brightest and strangest brains that had never been subject to military discipline' (Marinetti 1916d). In the light of these comments by Francioli and Marinetti, it is perhaps reasonable to conclude that the Army Command's reasons for disbanding the Volunteer Cyclists were not motivated solely by military tactics.

Although the Futurist intellectuals in the battalion may have tried the patience of some of the higher-ranking officers, others seemed well disposed towards them. It appears that Marinetti and Boccioni received some special treatment on account of their Futurist celebrity, although these seem to have been isolated occasions rather than the norm. While charged with guarding a fort on Lake Garda, a young Sardinian captain, Bellisai, invited the Futurists, including Marinetti, Boccioni and Sironi, to his room to discuss Futurist painting and architecture. According to Boccioni, 'everywhere Marinetti and I go we are immediately asked by officers to dine with them and so we manage to pass a few evenings like that' (Bellini 2006, 72). Marinetti claimed that during his reconnaissance missions he found many soldiers and lieutenants who 'love futurism, they know all of us and they want explanations' (Marinetti 1969, 61, emphasis in the original). While this may be an exaggeration on Marinetti's part, the other volunteers seem to have encouraged, or at least tolerated, the Futurists' poetry declamations and music, although on at least one occasion Marinetti's enthusiastic and loud declamation of Bombardamento di Adrianopoli while under fire by the Austrians was not well received by his lieutenant and he was ordered to be quiet (Marinetti 1916e).

\section{Futur-ising the mountains}

While fighting in Trentino served Marinetti's ideological purposes very well, there were aspects of the Alpine combat environment that were absolutely antithetical to Futurist ideals, and thus communicating his mountain combat experience to fellow Futurists was not unproblematic for him. Futurism was a resolutely urban movement, so being deposited in the rural landscape of Trentino was a potential stumbling block for Marinetti in conveying his Futurist sensibilities. In addition, a peculiar feature of Alpine warfare in the First World War was the fact that the technological developments which so shaped the experiences in the Western trenches had far less relevance in the harsh, mountainous landscape. This first wartime experience should have provided Marinetti with the opportunity to extol the beauty of mechanised, modern, technologically enhanced warfare; instead in the Alps warfare was of a 'seemingly primitive nature [... which] returned battle to the chivalrous age of war' (Keller 2009, 260). Similarly, Gibelli has observed that 'in certain respects it seemed like a pre-modern war, more reliant on mules than on trucks, more on sleds dragged by dogs and donkeys or on rope-ways than on armoured vehicles, more on inaccessible paths than on roads and railway tracks' $(1998,101)$. 
In order to overcome these two inconvenient facts, in his declarations and writings about his mountain experience Marinetti continually sought to describe the landscape using an urban and modern vocabulary and frame of reference. Whether destined for Futurist sympathisers or the general public, Marinetti transformed the landscape so that it would conform to Futurist visions of industrialised modernity. In a speech made to his fellow volunteer cyclists in September 1915 (and reported by La Gazzetta dello Sport), Marinetti characterised the mountains as providers of energy for urban and industrialised Italy, declaring that the mountains were 'favourable to the creation of electric energy and fertile flames favourable to the speed of trains' (Marinetti 1915b, 76-77). His interpretations of the Alpine landscape continued in these terms after his return from the front in Trentino, as he constantly endeavoured to enslave the mountains to Futurist ideals. In the two articles for La Gazzetta dello Sport, he described his experiences on the Monte Altissimo, again in explicitly urban terms, writing that on the mountain top:

... above our heads, the big grenades of our 149s are leaving like heavy trains that scrape along the tracks of great, curved bridges. They all converge on the other side of the lake, perfectly punctual, as if at a station at that Austrian trench of Colle del Bal. (Marinetti 1916d)

The practice of relating aspects of the wartime landscape to familiar features of one's civilian life is certainly not unique to Marinetti. The most frequently cited examples of such a practice are of soldiers renaming towns and villages behind the front line as well as christening the trenches with evocative names from their home countries and cities (Chasseaud 2006; Wilson 2011). As Wilson has observed in relation to British soldiers, such a process of naming 'ensured a sense of familiarity with their surroundings, a means of understanding the hostile, threatening landscape in which they were situated' (2011, 345). While Marinetti's urbanisation of the mountain environment can also be interpreted as an attempt to extract meaning from the conflict, his intentions differed markedly from those of the soldiers on the Western Front. That process of renaming was fuelled by a search for comfort in a dangerous environment, while Marinetti's evocation of urban images had a strong ideological basis, wholly absent in the process of 'tommifying' the trenches (Wilson 2011,338 ). In some cases the renaming of the trenches on the Western Front could be used as a shorthand to aid soldiers in their navigation of the labyrinthine structures (names such as 'Death Valley', 'Windy Corner' and 'Dead End' appear [Wilson 2011, 345]). Marinetti's references to the urban landscape were much more than observations of the landscape, however; they were the expression of his deeply felt Futurist beliefs. It is also significant that these references appear in works destined to be read by the general public, and so they had a specific function in propagating a 'Futurist' interpretation of the war.

It is, however, in his humorous 'self-help' manual Come si seducono le donne (How to Seduce Women), published in 1917, that Marinetti gives his fullest account of his interpretation of the meaning of the time he spent in mountain combat. It is clear that he was engaging in a process of meaning-making following his experiences at the front, and he appears incapable of interpreting them through anything but a Futurist lens. Such an approach has been defined as an 'associationist appreciation of nature' (Saito 2008, 154) meaning that we 'appreciate some natural objects primarily through historical/cultural/literary associations' (154).

According to Saito, an 'appropriate aesthetic appreciation of nature ... would involve listening to nature's own story and appreciating it on its own terms, instead of imposing our story upon it' (152, emphasis in the original). This is something Marinetti steadfastly refuses to do. For Marinetti, it was only the war which could confer meaning on the natural landscape and the concept that 'a natural object has its own unique history and function independent of the ... 
significance given by mankind' (Saito 2008, 155) was alien to him. Marinetti wrote that war 'confers real beauty on the mountains, the rivers, the forests' (Marinetti 1917, 40) and declared that he loved the mountains of Trentino for the first time because 'they had finally reacquired the essence of their soul, which is to be artillery' $(1917,40)$. Similarly, the purpose of the valleys was to reverberate with the sounds of cannons. Marinetti deemed nature to be incomplete without war, and stated that it was war which endowed a new purpose on the mountainous landscape:

Today the aggressive shapes of the high mountains have a reason to exist, all covered by thick trajectories, by the curved hisses and roars of the cannons. The rivers - natural trenches - today have a logical life. They interrupt the strength of the enemy and empty the battlefields of the bodies which they drag to the sea. (Marinetti 1917, 37)

In Marinetti's view, the natural environment was only a valid space when it had been affected by human intervention. According to the associationist principle, "nature is not appreciable until it is "humanised" or "consecrated" by some human deed, either actual or imaginary.... The natural object is appreciable as a means to celebrating our historical/cultural/literary events and accomplishments' (Saito 2008, 154). In fact, Marinetti is particularly enthusiastic when describing the destruction wrought on the mountain landscape by the war as the industrialisation of the countryside had been accelerated. While in the past mountains had been gutted by winding tunnels, now they 'are decapitated by colossal mines' (Marinetti 1917, 40). In this way, the romantic sense of solitude typically associated with the Alpine environment could be destroyed: 'the long and patient zig-zagging mule tracks are cancelled out by the flying straight lines of the aeroplanes' $(1917,40)$.

Even before the war, Marinetti had occasion to observe the impact of aviation on the perception of distance and speed. He was present in September 1909 in Brescia at Italy's first national air show. Many similar events were held all over Italy in subsequent years and they were widely reported by the media. A special highlight of some was a flight across the Alps, the first of which took place as part of Milan's first international air show between 24 September and 3 October 1910 (Berghaus 2009, 10-11). As Berghaus has discussed, Marinetti 'presented the machine as a vehicle for overcoming the restrictions of given nature and unleashing the emancipatory quality of created nature'. The machine would symbolise his 'Futurist vision of an industrialised environment forming a "second Nature" working to the advantage of humankind... Through the machine, the human being became a demiurge who creates a Nature that is superior to the one made by God' $(2009,20)$. This interpretation of Marinetti's fetishisation of the machine is also applicable to his attitude in the mountains of Trentino and the opinions expressed in Come si seducono le donne. The man-made environment, transformed by war, surpassed the traditional religious and nostalgic associations of nature and landscape. Marinetti had already written, in 1911, a manifesto which expressed the Futurist contempt for the Symbolists and 'those who defend the aesthetics of Nature' (Marinetti 1911b, 45). This manifesto was an attack on Romantic and Symbolist conceptions of the natural environment and the mountains were one of the targets for this invective. Marinetti characterised himself and his fellow Futurists as those "who have dared to step naked from the river of time and who create ... new springs of heroism that sing, new torrents that deck the mountain in scarlet' (Marinetti $1911 \mathrm{~b}, 43)$. His intention was to 'destroy the poetry of far-off times, of faraway places and of solitude in the wild' and he declared that 'our Futurist sensibility is no longer moved by the dark mystery of an unexplored valley or of a mountain gorge' (1911b, 44). Much as he would in Come si seducono le donne, in this manifesto Marinetti praised the 'multicolored billboards in the 
green meadows, iron bridges which chain the hills together, surgical trains that cut through the blue belly of the mountains, huge turbines' (1911b, 45). It was only, however, during his time spent in Trentino that Marinetti could see these developments first-hand and witness the mountains truly 'decked in scarlet'. Marja Härmänmaa has argued that 'in Marinetti's cosmology ... Nature is characterised by aggressive and violent forces ... Respect if not fear towards the forces of Nature seems to be a fundamental element in Marinetti's ideology' (2009, 339). While this judgement holds true for Marinetti's early Futurist works (including Mafarka il futurista and Zang Tumb Tumb), I would argue that after his first combat experiences in 1915 this attitude of respect is far less evident, and has been replaced, for the most part, with a firm belief in Futurist and man-made superiority over the natural environment.

Such an attitude of praising the war's destructive transformation of the mountain landscape is absolutely at odds with the experiences of other soldiers in the Alps during the First World War. Italian officers tended to describe the beauty of the environment (for example Omodeo 1968, 94-95; Campana 1993, 29), the contemplation of which often encouraged them to view the mountains in spiritual or religious terms (Omodeo 1968, 95-96; Rigillo 2008, 75-76). A similar tendency has been reported in relation to German and Austrian experiences in the mountains where 'the overwhelming beauty of the Alpine landscape provided respite from the machinery of war.... Many felt the beauty of the mountains transcended the war' (Keller 2009, 267). Many ordinary Italian soldiers, however, considered the mountains boring and ugly: one commented in a letter of April 1915: "when you write to me I want to know how everything is with my land; because here in these high mountains covered with snow you hardly know or see anything' (Bellosi and Savini 2002, 208), and such opinions were not unusual. Similarly to Marinetti, these officers and soldiers were adopting an associationist attitude towards nature by interpreting it exclusively in anthropocentric terms. Nonetheless, Marinetti's view differed from these perspectives: he did not find the mountains particularly beautiful or ugly, nor did they inspire any religious or spiritual reflection on his part. Rather, he had a utilitarian view of the Alpine environment and related to it only in so far as it could be useful to him in the furthering of his political and Futurist ideals.

A peculiar feature of Marinetti's wartime writings is the 'absolute absence of silence, of interior space' (Isnenghi 2007, 180). Although Isnenghi here is referring to the semiautobiographical novel L'Alcova d'acciaio, published in 1921, which recounts Marinetti's last few months of war in 1918, the observation is applicable also to his earlier experiences in Trentino in 1915. The one exception to this tendency, and the only time when Marinetti appears to have contemplated his own mortality with the experience of combat, was immediately before and during the battle of Dosso Casina in October 1915. The night before the assault began, Marinetti wrote a letter to Paolo Buzzi and Francesco Balilla Pratella, in which his fear of death is evident:

The battle will be serious, I am happy to give my life to our great, strong and glorious Italy .... I hope I am not killed tomorrow so that I can continue to slaughter Austrians and to see the undoing of passéist Austria, most hated enemy. I hope I am not killed tomorrow so that I can take up again with you the great futurist struggle. (Marinetti 1969, 57)

As Wilcox has discussed, 'fear for oneself was expressed tangentially through other emotions such as empathy for others in the forms of grief or mutual concerns, perhaps more socially acceptable than admitting to fear for one's own safety' $(2012,176)$. Marinetti follows this pattern by only addressing his fear of death indirectly in relation to his antiAustrian sentiment and by concealing it behind Futurist bombast. This more contemplative 
side to Marinetti is also reflected in the words-in-freedom drawing 'Con Boccioni a Dosso Casina' ('With Boccioni at Dosso Casina') (published in L'Italia Futurista in August 1916). Marinetti was the head of a lookout party one hundred metres from the Austrian trenches and there is an intense fear detectable in his evocation of the 'restless work', 'anxiety to return to the trenches', 'terror of the last escape in our bones' (1916b). They were afraid even of coughing in case it would alert the Austrians. The drawing features varying font styles and sizes and there is an onomatopoeic portrayal of the sounds that reach him high in the mountains. However, the words 'almost total silence' (1916b) appear four times, each time in large, bold type, and once the phrase 'Total darkness + Total silence' (1916b), which is suggestive of an unusually contemplative side to Marinetti. In his typical streamof-consciousness style, which lacks punctuation, he described the 'dark freezing weight of the night pensive fixity of the mountains pre-historic calm of the enormous dewlaps' (1916b). In stressing the size of the mountains, Marinetti showed himself to be in awe of them for the first time.

More representative of Marinetti's experiences of combat at the front is the words-infreedom drawing 'Battaglia a 9 piani' ('Nine-storey battle') (1916a) (Figure 1) which features none of the reflexivity of 'Con Boccioni a Doso Casina'. 'Battaglia a 9 piani' shows a crosssection of the mountains with Lake Garda in the middle. One side is Austrian, the other is Italian. The drawing was published in January 1916 on the front page of the periodical Vela Latina, which was affiliated with Futurism and featured one or two Futurist pages in every issue between October 1915 and March 1916. In the same year, Marinetti produced another version of the image, having made a small number of minor changes to it, and dedicated it to the Futurist artist Fortunato Depero (Figure 1). John White has called 'Battaglia a 9 piani' an example of Marinetti's 'war reportage', writing that 'Marinetti's dual authority as renowned modernist poet and eyewitness to a number of historically prestigious battles underwrites Italian Futurism's patriotic campaign to persuade fellow countrymen to abandon their neutralist stance' (White $2010,129)$. However, given that the drawing was published in a publication which was very closely aligned with Futurism, Marinetti was more likely preaching to the converted rather than reaching out to neutralists, as White suggests. Commenting on the drawing, Johanna Drucker has written that 'without, apparently, seeing any paradox in this whatsoever, [Marinetti] made one of his most orderly typographic arrangements in order to depict the chaos of battle' $(1994,131)$. I must, however, disagree with Drucker's assessment of this image. Marinetti's aim was not to depict the chaos of battle; on the contrary he wished to underline the positive aspects of this mountain combat and its essentially Futurist nature. This drawing must be analysed in the context of Marinetti's desire to 'urbanise' and 'modernise' the mountains: they are called 'skyscrapers' (1916a), and their sunny peaks are the 'bright advertising of Italy' (1916a). Not only did Marinetti claim the mountains for Italy, but he also expressly defined them as 'Futurist mountains' (1916a). Depicting the battles in the mountains as 'chaotic', as Drucker would prefer, would have been counterproductive for Marinetti. He wanted to exalt the actions of the Futurist soldiers, professing the Futurists to be masters of this inhospitable environment. In line with his desire to 'futur-ise' the mountain landscape, Marinetti also heralded the 'crazy revolt of the Futurist mountains' (1916a) which would crush peace, nostalgia, the sky and love. All the traditional associations of mountaineering and the mountain landscape (see Wedekind and Ambrosio 2007) have been destroyed by the Futurists' activities. Thus, Marinetti succeeded in reconciling his urban, Futurist movement with the rural, mountainous landscape of Trentino by interpreting the environment in urban and technological terms, and by underlining the positive aspects of combat. 


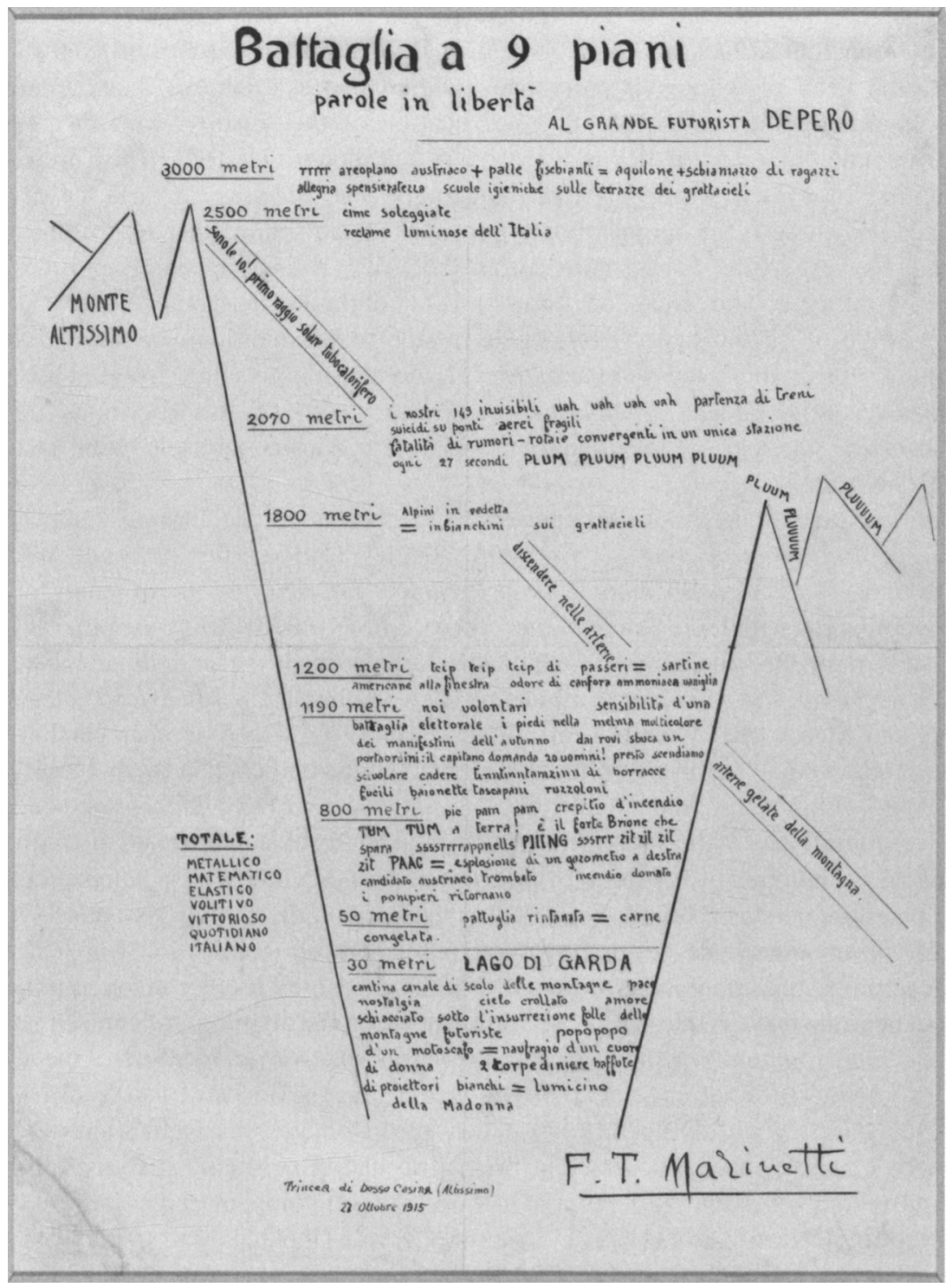

Figure 1. Filippo Tommaso Marinetti, Battaglia a 9 piani, 1916. Courtesy of Museo d'Arte Moderna e Contemporanea di Trento e Rovereto.

\section{Futurist alpini}

Marinetti not only reflected on the mountain landscape, but also on the soldiers who were most associated with it - the Alpine soldiers or alpini. Very soon after the formation of the alpini in 1872 , the alpino had assumed a place in the Italian consciousness as a champion and defender of the nation (see Todero 2003). He was the 'protagonist of a warrior myth ... an exceptional soldier because [ ... he is] descendent of mountain stock, which allows only the strongest, the most able and the most determined to survive' (Mondini 2008, viii). In the context of the German 
army, George Mosse has discussed how the mountains 'stood above all for the revitalisation of the moral fibre of the Volk and its members' $(1990,114)$, and the Alpine soldiers fulfilled a similar function in the Italian situation.

The conditions on the Alpine front were certainly harsh. The alpini fought at over 3000 metres and the war in the mountains saw more soldiers die as a result of natural factors than of the direct effects of combat and artillery fire (Gibelli 1998, 101). By the autumn and winter of 1915, when Marinetti was fighting in Trentino, the image of the alpini as representatives of the Italian wartime spirit had already deeply penetrated the public consciousness, not least as a result of the drawings in the widely circulated illustrated newspapers L'Illustrazione Italiana and La Domenica del Corriere (see Critelli 2006). Achille Beltrame's illustrations in the latter newspaper are the most famous and in the summer of 1915 a number of issues prominently featured the courageous exploits of the Alpine divisions. Notable in this regard is the front cover of the 4-11 July issue of La Domenica del Corriere which features an alpino hanging off a sheer cliff face, suspended from a rope tied around his shoulder, aiming his gun at a group of Austrian soldiers below. The Volunteer Cyclists fought alongside the Alpine soldiers on the shores of Lake Garda and both in speeches made at the front and in articles and manifestos written after his return, Marinetti was keen to exploit the positive associations embodied by the alpini and to align himself and his fellow Futurists with these brave soldiers.

In addition to the two articles which appeared in La Gazzetta dello Sport in January and February 1916, Marinetti also issued a Futurist manifesto, 'Orgoglio Futurista' ('Futurist Pride'), on his experiences in Trentino in January 1916. While the material covered in these different publications was very similar, Marinetti tailored his language and perspective in order to meet the demands of his readers, whether Futurists reading the manifesto, or the general public reading the newspaper articles. In the articles for La Gazzetta dello Sport, Marinetti adopted an inclusive perspective and emphasised the difficulty of the training and the conditions experienced by the Volunteer Cyclists in general, without making specific references to how the Futurists endured these hardships. He wrote that the Volunteer Cyclists:

... broke all records of transformation, patience, agility, impetus, speed .... The most diverse forms of activity, the struggles, the hard-working energy of bees, maximum discomfort from bad weather, pain and the exertion of a caravan of Siberian prisoners, all the most difficult, painful and thrilling things that patriotism can impose on Garibaldian hearts was withstood and experienced by us with ease. (Marinetti 1916d)

A recurring feature of both the newspaper articles and the Futurist manifesto of January 1916 is the references to how the Volunteer Cyclists were transformed into the alpini they fought alongside, thus significantly raising their military status and prestige. What is significant is that when writing for La Gazzetta dello Sport, Marinetti treated the Volunteer Cyclists as a single unit, writing 'and there we were completely transformed into alpini' (1916d) and he never singled out the Futurist soldiers for specific praise in this regard. By contrast, in the Futurist manifesto, although he did make a passing reference to the Volunteer Cyclists in general who had 'suddenly become alpini' (1916c, 503), his attention was firmly focused on highlighting the strengths of the Futurist volunteers. Marinetti stated that while exploring and occupying a trench on the front line with Boccioni, Sant'Elia and Anselmo Bucci, they established that 'young Italian painters and poets can transform themselves into daring, rough, tireless alpini' (1916c, 502).

Despite this desire to identify the Volunteer Cyclists and the Futurists with the Alpine corps, Marinetti also drew explicit contrasts between the conditions they endured compared with those experienced by the alpini whom they fought alongside. In this instance, Marinetti did not distinguish in his different texts between the Volunteer Cyclists and the Futurists. In La Gazzetta 
dello Sport, he commented that 'the provision of fresh supplies which functioned as normal for the alpini, had not yet been organised for us' (1916e) and that 'the alpini have magnificent accommodation ... we, on the other hand, live the tragic life of medieval lepers and mad dogs chased by gunshots' (1916e). In the manifesto, he also underlined the lack of preparation the Volunteer Cyclists had to endure. They were 'not trained for mountain warfare' (1916c, 502) and they had to walk for days in thick fog in temperatures of minus 15 degrees wearing almostsummer uniforms. The contrast with the highly specialised and highly trained Alpine soldiers is clear, and so by demonstrating how the Volunteer Cyclists and Futurists survived the same conditions with inferior supplies, Marinetti was actually implying and suggesting that they possessed a strength and resistance superior to that of the alpini.

By contrast, in a speech made to other soldiers on 20 September 1915 while behind the front lines, and later published in La Gazzetta dello Sport, Marinetti was keen to downplay any suggestion that the Futurist soldiers regarded themselves as an elite group within the army. In this speech, he explicitly distanced himself from middle-class intellectuals and positioned himself alongside the men of action, the mountain soldiers (Marinetti 1915b). He was attempting to relate to the simplicity of the alpino, the 'sons of the mountains' (Battisti 1916, 6) whose virtues Cesare Battisti would extol in his famous address to the Società Dante Alighieri just a few months later, in April 1916. In the text subsequently published by Treves, Battisti described the poverty, isolation and lack of pretension of the alpini, and stressed how:

... they knew nothing of the fervour that reigned in the one hundred cities of Italy from March to May, nothing of the magnificent preparations of the populations of the cities and towns who listened to the words of the best political minds. (Battisti 1916, 11-12)

Marinetti, speaking to the soldiers in September 1915, stressed the need for a well-trained body over a finely tuned mind, stating that 'Italy must ... always be muscularly ready for all kinds of exertion: steady nerves, certain instincts and well-trained muscles are needed.... A strong Italian, perfect in his powerful physical balance will be bestowed with honour and glory' (1915b, 77). Even before Italy's entry into the war, in an interview of February 1915, Marinetti had foreseen the potential conflict between Futurism's bourgeois following and a mass conflict on an unprecedented scale. In that interview, he had declared that:

We artists, alive at last, no longer aloft on the scornful peaks of aestheticism, wished to participate as soldiers and workmen in the progress of the world.... Hands dirty from digging trenches but equally adept with the pen, the rudder, the steering wheel, the chisel, the slap in the face, and the rifle. (1915c, 239)

A few months later at the front in the speech to fellow soldiers, Marinetti expressed a similar idea, but now from the perspective of an active soldier. With the advent of the war, the cultural obsession which plagued certain types of Italians would be combated and 'finally, the thousands of erudite Italians nailed with paralysis among mountains of books will be neglected' (1915b, 77). The difference between the intellectuals mired in metaphorical mountains of books and the soldiers who are fighting in the real mountain landscapes of Trentino is very clear. Ever the skilful manipulator, Marinetti attempted to overturn the perception of Futurism as the preserve of the urban middle classes, by aligning his movement with the tide of public opinion which sympathised with the simplicity of the ordinary soldier.

\section{Conclusion}

Although Marinetti had been a war correspondent during both the Italo-Turkish war of 1911 and during the Bulgarian-Turkish conflict in 1912, fighting with the Volunteer Cyclists was his first 
direct experience of combat. During this time, he was an ordinary private soldier, a lowly status he often found hard to manage. Occasional contact with the officer class was not enough to alleviate these feelings of discontent. After spending most of 1916 engaged in cultural and theatrical pursuits on the home front, Marinetti returned to the army as an officer in the autumn of that year, where his experiences would differ markedly from those first months on the front line in Trentino. As an officer, he was permitted to 'move in and out of the war zone more or less as it pleased him' and he gave speeches and lectures all over Italy 'making propaganda for the war effort rather than being fully engaged in front-line combat' (Berghaus 1996, 83). Isnenghi has also observed that this unusual freedom of movement meant that Marinetti's later experiences corresponded almost to a 'private war' (2007, 179, emphasis in the original). Away from the physical realities of the mountain landscape, Marinetti ceased, for the most part, to reflect on it and on the Alpine soldiers and no longer used them as a propaganda tool for Futurist purposes.

This analysis of Marinetti's time spent in Trentino in 1915 and the texts that were inspired by it has revealed how he engaged in a process of meaning-making both during and after his experience in the Alpine landscape. Marinetti consistently imposed his own Futurist views onto the landscape rather than allowing the landscape to impinge on him on its own terms. For Marinetti, the mountains represented a functional tool that he could employ to advance his political and artistic aims and, with the one exception of 'Con Boccioni a Dosso Casina', the inhospitable environment never gave him cause to reflect on death or his own mortality. Depending on the audience he was addressing, he manipulated his perspective in order to achieve maximum support for the Futurist movement. On the one hand, he sought to distance Futurism from being identified with erudition by recasting the Futurists as 'men of action' who had more in common with the ordinary soldier than the bourgeois intellectual. On the other hand, he ensured that he met the expectations of his Futurist followers by implying a superiority over the alpini and by interpreting the hostile Alpine environment using the established codes and rhetoric of Futurism, namely the praise of the urban, technological and modern world.

\section{Acknowledgements}

The author is grateful to the three anonymous reviewers of an earlier draft of this paper for their comments and suggestions. The author is in receipt of funding from the Irish Research Council.

\section{Notes}

1. Unless otherwise indicated, all translations are by the author.

2. In fact, when Marinetti attempted to enlist in May 1915 he was refused because of a hernia. He went immediately to have the necessary operation and, once he had recovered, departed for the front.

3. On the relationship between Futurism, war and nationalism, see Sanguineti (1975), Gentile (1988), Mosse (1988) and Adamson (2010). On the historiography of Futurism, see Adamson (2008).

\section{Notes on contributor}

Selena Daly is an Irish Research Council Post-Doctoral Research Fellow in the School of History and Archives at University College Dublin, and was a Lecturer in Italian at Manchester Metropolitan University from 2010 to 2012. Her publications include The European Avant-Garde: Text and Image, co-edited with Monica Insinga (Newcastle-upon-Tyne: Cambridge Scholars Publishing, 2012), "Arrigo Boito e Filippo Tommaso Marinetti tra il Reale e l'Ideale" Otto/Novecento (Special issue on the Scapigliatura) 36 (3) (2012), "From Symbolism to Futurism: Poupées Électriques and Elettricità," Rivista di Studi Italiani 28 (1) (2010) and "Le Roi Bombance: The Original Futurist Cookbook?" in Back to the Futurists: The Avant- 
Garde and its Legacy, edited by Elza Adamowicz and Simona Storchi (Manchester: Manchester University Press, 2013, forthcoming).

\section{References}

Adamson, W. L. 2008. "Fascinating Futurism: The Historiographical Politics of an Historical AvantGarde." Modern Italy 13 (1): 69-85.

Adamson, W. L. 2010. "How Avant-Gardes End - and Begin: Italian Futurism in Historical Perspective." New Literary History 41 (4): 855-874.

Amat, J.-P. 1997. "Les effets de la Grande Guerre sur les paysages entre Argonne et Woëvre." Enquêtes Rurales 2: 123-152.

Armiero, M. 2010. "Natural and Political Landscapes in World War I." In Nature and History in Modern Italy, edited by M. Armiero, and M. Hall, 231-250. Athens: Ohio University Press.

Armiero, M. 2011. A Rugged Nation: Mountains and the Making of Modern Italy. Cambridge: White Horse.

Battisti, C. 1916. Gli alpini. Milan: Treves.

Bellini, D., ed. 2006. Con Boccioni a Dosso Casina: I testi e le immagini dei futuristi in battaglia. Rovereto: Nicolodi.

Bellosi, G., and M. Savini, eds. 2002. Verificato per censura. Lettere e cartoline di soldati romagnoli nella prima guerra mondiale. Cesena: Il Ponte Vecchio.

Berghaus, G. 1996. Futurism and Politics: Between Anarchist Rebellion and Fascist Revolution, 1909_ 1944. Providence: Berghahn.

Berghaus, G. 2009. "Futurism and the Technological Imagination Poised between Machine Cult and Machine Angst." In Futurism and the Technological Imagination, edited by G. Berghaus, 1-39. Amsterdam: Rodopi.

Brantz, D. 2009. "Environments of Death: Trench Warfare on the Western Front, 1914-1918." In War and the Environment: Military Destruction in the Modern Age, edited by C. Closmann, 68-91. College Station: Texas A\&M University Press.

Campana, M. 1993 [1918]. Un anno sul Pasubio, edited by A. Massignani. Novale di Valdagno: Rossato.

Chasseaud, P. 2006. Rat's Alley: British Trench Names of the Western Front, 1914-1918. Staplehurst: Spellmount.

Codara, R. 1915a. "I VCA di Milano sono partiti per il fronte." La Gazzetta dello Sport, July 26.

Codara, R. 1915b. "L'ora triste pei VCA. Congedo e scioglimento." La Gazzetta dello Sport, December 6.

Corà, V. 2008. "La guerra in montagna." In La Grande Guerra, 2 vols, edited by M. Isnenghi, and D. Ceschin, vol. 2, 647-655. Turin: UTET.

Critelli, M. P. 2006. "L'alpestre faccia dell'eroe. La montagna tra simbolo e panorama." In Der Erste Weltkrieg im Alpenraum. Erfahrung, Deutung, Erinnerung/La Grande Guerra nell'arco alpino. Esperienze e memoria, edited by H. J. W. Kuprian, and O. Überegger, 61-72. Innsbruck: Universitätsverlag Wagner.

Drucker, J. 1994. The Visible Word: Experimental Typography and Modernist Art (1909-1923). Chicago: University of Chicago Press.

État-Major de l'Armée. 1908. "Il Corpo Nazionale dei Volontari Ciclisti e Automobilisti." Revue militaire des armées étrangères 969: 186-188.

Francioli, G. 2008. "Interview with M.R. Lecce [1980]. In "Il filo tenace di una ricerca, 1978-2008: Da un ritaglio di giornale a un inedito video-documentario sul futurismo" by F. Franco, 37-41. In Futuristi a Dosso Casina, exhibition catalogue Museo di Riva del Garda, July 12-November 2 2008, edited by L. Sansone. Milan: Mazzotta.

Franzina, E., ed. 2003. Una trincea chiamata Dolomiti 1915-1917. Una guerra, due trincee/Ein Krieg zwei Schützengräben. Udine: Paolo Gaspari.

Fussell, P. 1975. The Great War and Modern Memory. New York: Oxford University Press. 
Gentile, E. 1988. "Il futurismo e la politica. Dal nazionalismo modernista al fascismo (1909-1920)." In Futurismo, cultura e politica, edited by R. De Felice, 105-159. Turin: Fondazione Giovanni Agnelli.

Gibelli, A. 1998. La Grande Guerra degli italiani, 1915-1918. Florence: Sansone.

Härmänmaa, M. 2009. "Futurism and Nature: The Death of the Great Pan?" In Futurism and the Technological Imagination, edited by G. Berghaus, 337-360. Amsterdam: Rodopi.

Helphand, K. I. 2006. Defiant Gardens: Making Gardens in Wartime. San Antonio, TX: Trinity University Press.

Isnenghi, M. 2007. Il mito della Grande Guerra. 7th ed. Bologna: Il Mulino.

Keller, T. 2009. "The Mountains Roar: The Alps during the Great War." Environmental History 14 (2): $405-421$.

Kuprian, H. J. W., and O. Überegger, eds. 2006. Der Erste Weltkrieg im Alpenraum. Erfahrung, Deutung, Erinnerung/La Grande Guerra nell'arco alpino. Esperienze e memoria. Innsbruck: Universitätsverlag Wagner.

Leoni, D. 2007. "Guerra di montagna/Gebirgskrieg." In La prima guerra mondiale, edited by S. AudoinRouzeau and J.-J. Becker, Italian ed. edited by A. Gibelli, 2 vols, vol. 1, 237-246. Turin: Einaudi.

Marinetti, F. T. 1909a. "Foundation and Manifesto of Futurism." In Critical Writings, edited by G. Berghaus, translated by D. Thompson, 11-17. New York: Farrar, Straus and Giroux, 2006.

Marinetti, F. T. 1909b. "Second Futurist Proclamation: Let's Kill off the Moonlight." In Critical Writings, edited by G. Berghaus, translated by D. Thompson, 22-31. New York: Farrar, Straus and Giroux, 2006.

Marinetti, F. T. 1911a. "Second Futurist Political Manifesto." In Critical Writings, edited by G. Berghaus, translated by D. Thompson, 73-74. New York: Farrar, Straus and Giroux, 2006.

Marinetti, F. T. 1911b. "We Renounce our Symbolist Masters, the Last of All Lovers of the Moonlight." In Critical Writings, edited by G. Berghaus, translated by D. Thompson, 43-46. New York: Farrar, Straus and Giroux, 2006.

Marinetti, F. T. 1912. "Technical Manifesto of Futurist Literature." In Critical Writings, edited by G. Berghaus, translated by D. Thompson, 107-119. New York: Farrar, Straus and Giroux, 2006.

Marinetti, F. T. 1913. "Third Futurist Political Manifesto." In Critical Writings, edited by G. Berghaus, translated by D. Thompson, 75-77. New York: Farrar, Straus and Giroux, 2006.

Marinetti, F. T. 1915a. "Movimento politico futurista." In Teoria e invenzione futurista, 6th ed., edited by L. De Maria, 337-341. Milan: Mondadori, 2005.

Marinetti, F. T. 1915b. "Speech to fellow soldiers," in R. Codara, "La celebrazione sportiva e futurista del venti settembre fra i volontari ciclisti-automobilisti." La Gazzetta dello Sport, September 27. In Con Boccioni a Dosso Casina: I testi e le immagini dei futuristi in battaglia, edited by D. Bellini, 73-78. Rovereto: Nicolodi, 2006.

Marinetti, F. T. 1915c. "The Meaning of War for Futurism: Interview with L'Avvenire." In Critical Writings, edited by G. Berghaus, translated by D. Thompson, 238-244. New York: Farrar, Straus and Giroux, 2006.

Marinetti, F. T. 1915d. "Trieste, la nostra bella polveriera." In Teoria e invenzione futurista, 6th ed., edited by L. De Maria, 289-290. Milan: Mondadori, 2005.

Marinetti, F. T. 1916a. "Battaglia a 9 piani." Vela Latina 4 (1), January 8.

Marinetti, F. T. 1916b. "Con Boccioni a Dosso Casina." L'Italia Futurista 1 (6), August 25.

Marinetti, F. T. 1916c. "Orgoglio italiano." In Teoria e invenzione futurista, 6th ed., edited by L. De Maria, 502-506. Milan: Mondadori, 2005.

Marinetti, F. T. 1916d. "Quinte e scene della campagna del Battaglione Lombardo Volontari Ciclisti sul lago di Garda e sull'Altissimo. Parte I." La Gazzetta dello Sport, January 31.

Marinetti, F. T. 1916e. "Quinte e scene della campagna del Battaglione Lombardo Volontari Ciclisti sul lago di Garda e sull'Altissimo. Parte II." La Gazzetta dello Sport, February 7.

Marinetti, F. T. 1917. Come si seducono le donne. Reprint of 1st ed., with introduction by G. Agnese. Florence: Vallecchi, 2003. 
Marinetti, F. T. 1969. Lettere ruggenti a F. Balilla Pratella. Marinetti, Papini, Balbo, Boccioni, De Pisis, Severini, Folgore, Mascagni, Russolo, edited by G. Lugaresi. Milan: Quaderni dell'Osservatore.

Marinetti, F. T. 1987. Taccuini, 1915-1921, edited by A. Bertoni. Bologna: Il Mulino.

Mondini, M. 2008. Alpini: Parole e immagini di un mito guerriero. Rome: Laterza.

Mosse, G. 1988. "Futurismo e cultura politica in Europa: una prospettiva globale." In Futurismo, cultura e politica, edited by R. De Felice, 13-31. Turin: Fondazione Giovanni Agnelli.

Mosse, G. 1990. Fallen Soldiers: Reshaping the Memory of the World Wars. New York: Oxford University Press.

Omodeo, A. 1968. Momenti della vita di guerra. Dai diari e dalle lettere dei caduti 1915-1918. Turin: Einaudi.

Pearson, C. 2012. "Researching Militarized Landscapes: A Literature Review on War and the Militarization of the Environment." Landscape Research 37 (1): 115-133.

Rigillo, M. 2008. Dentro la guerra: lettere dal fronte della Valle del Chiese 1915-1916, edited by G. Poletti. Storo: Associazione Il Chiese.

Saito, Y. 2008. "Appreciating Nature on Its Own Terms." In Nature, Aesthetics, and Environmentalism: From Beauty to Duty, edited by A. Carlson, and S. Lintott, 151-168. New York: Columbia University Press.

Sanguineti, E. 1975. "La guerra futurista." In Ideologia e linguaggio. Milan: Feltrinelli.

Sansone, L. 2008. "Ugo Piatti e il Battaglione Lombardo Volontari Ciclisti Automobilisti." In Futuristi a Dosso Casina, exhibition catalogue Museo di Riva del Garda, July 12-November 2 2008, edited by L. Sansone, 11-36. Milan: Mazzotta.

Saunders, N. J. 2003. Trench Art: Materialities and Memories of War. Oxford: Berg.

Todero, F. 2003. "Alpini, guerra in montagna e letteratura: la nascita di un mito." In Una trincea chiamata Dolomiti 1915-1917. Una guerra, due trinee/Ein Krieg - zwei Schützengräben, 81-90. Udine: Paolo Gaspari.

Wedekind, M., and C. Ambrosio, eds. 2007. Alla conquista dell'immaginario: l'alpinismo come proiezione di modelli culturali e sociali borghesi tra Otto e Novecento. Treviso: Edizioni Antilia.

White, J. J. 2010. "Iconic and Indexical Elements in Italian Futurist Poetry: F.T. Marinetti's 'words-infreedom'." In Signergy, edited by J. C. Conradie, R. Johl, M. Beukes, O. Fischer, and C. Ljungberg, 129-156. Amsterdam: John Benjamins.

Wilcox, V. 2012. “'Weeping tears of blood': Exploring Italian Soldiers' Emotions in the First World War." Modern Italy 17 (2): 171-184.

Wilson, R. J. 2011. “'Tommifying' the Western Front, 1914-1918.” Journal of Historical Geography 37 (3): $338-347$.

Wilson, R. J. 2012. Landscapes of the Western Front: Materiality during the Great War. New York: Routledge. 